\title{
Pendekatan Interdisipliener Hukum Ekonomi Dalam Pembangunan Sistem Hukum Ekonomi Nasional
}

Oleh :

Tri Hastuti, S.H., M.H.

\begin{abstract}
Abstrak
Pemanfaatan sumber daya yang terbatas menyebabkan perlunya suatu perangkat hukum yang dapat mengatur agar semua pihak yang berkepentingan mendapat perlakuan yang adil (win-win solution) dan agar tidak terjadi perselisihan diantara pelaku ekonomi. Fungsi hukum salah satunya adalah mengatur kehidupan manusia bermasyarakat di dalam berbagai aspek. Manusia melakukan kegiatan ekonomi untuk memenuhi kebutuhannya. Manusia tidak bisa memenuhi kebutuhannya sendiri, oleh karena itu manusia melakukan interaksi dengan manusia lainnya. Interaksi ini sering kali tidak berjalan dengan baik karena adanya benturan kepentingan diantara manusia yang berinteraksi. Agar tidak terjadi perselisihan maka harus ada kesepakatan bersama diantara mereka. Kegiatan ekonomi sebagai salah satu kegiatan sosial manusia juga perlu diatur dengan hukum agar sumber daya ekonomi, pemanfaatan dan kegiatannya dapat berjalan dengan baik dengan mempertimbangkan sisi keadilan bagi para pelaku ekonomi. Hukum atau peraturan perekonomian yang berlaku disetiap kelompok sosial atau suatu bangsa berbeda-beda tergantung kesepakatan yang berlaku pada kelompok sosial atau bangsa tersebut.
\end{abstract}

Kata Kunci : Adil, Hukum, Ekonomi

\section{INTER DICIPLINARY APPROACH OF ECONOMIC LAW IN THE DEVELOPMENT OF NATIONAL ECONOMIC LEGA SYSTEM}

\begin{abstract}
Utilization of limited resources led to the need for a legal instrument that can be arranged for all interested parties receive fair treatment (win-win) and in order to avoid disputes among economic actors. The function of law one of which is to regulate human life society in various aspects. Human economic activity to meet their needs. Humans can not meet its own needs, therefore humans interact with other humans. These interactions often do not work well because the conflict of interest between people interacting. To avoid disputes, there must be agreement between them. Economic activities as one of the human social activities also need to be regulated by law in order to economic resources, utilization and activities can be run well by considering the perspective of justice for economic actors. Economy laws or regulations applicable in each social group or a nation
\end{abstract}


vary depending on the agreement that applies to the social group or nation.

\section{Keywords: Fair, Law, Economics}

\section{A. Pendahuluan}

Keterbukaan dan kebebasan dalam berbagai bidang kehidupan mengakibatkan perubahan dalam berbagai aspek kehidupan berlangsung sangat cepat. Melalui keterbukaan informasi kegiatan ekonomi menjadi bersifat terbuka pula sehingga mengakibatkan transaksi ekonomi dapat dilakukan dimana saja dan kapan saja. Namun tentu harus mengikuti aturan-aturan yang tertentu pula, yang dikenal dengan hukum ekonomi.

Pada tahun 1930-an baru dimulai menggunakan kacamata Hukum Ekonomi, yang pada waktu itu baru mencakup peraturan administrasi negara yang membatasi kaidah hukum perdata dan dagang. Bertambahnya kaidah hukum dalam segala bidang mengubah ciri hukum ekonomi dari droit economique, menjadi droit de l'economic, yaitu sebagai kaidah hukum yang berserakan di semua bidang hukum, tidak saja pada bidang hukum perdata dan hukum dagang, tetapi juga bidang hukum tata negara, hukum pidana, pidana internasional, hukum pajak, dan hukum administrasi negara. Sehingga kaidah hukum ekonomi bukan saja bertambah secara kuantitatif, melainkan juga secara kualitatif. ${ }^{1}$

Perkembangan hukum ekonomi sebagai akibat berkembangnya pranata-pranata ekonomi dalam kegiatan, juga melahirkan pranata hukum baru yang mengatur tentang regulasi perekonomian di Indonesia. Sejalan dengan perkembangan tersebut, maka bentuk-bentuk kegiatan ekonomi di era globalisasi ini terus berkembang cepat

1 Jimly Assiddiqie, Konstitusi Ekonomi, 2010: Jakarta: PT Kompas Media Nusantara, hlm. 76. mengikuti perkembangan bentuk-bentuk kegiatan usaha.

Kegiatan ekonomi merupakan suatu rangkaian kegiatan yang dilakukan oleh manusia dalam rangka memenuhi kebutuhannya, baik kebutuhan primer, sekunder, maupun tersier. Kegiatan-kegiatan tersebut sudah dimulai sejak awal peradaban manusia dan berlanjut sampai saat ini. ${ }^{2}$ Pembangunan ekonomi adalah suatu proses yang berlangsung dalam jangka waktu yang panjang dan lama dalam suatu masyarakat negara yang bertujuan untuk meningkatkan pendapatan perkapita suatu bangsa. Pembangunan ekonomi juga bertujuan untuk memaksimalkan cara dalam rangka memenuhi kebutuhan manusia dengan cara mentransformasi faktor-faktor ekonomi yang ada pada suatu kondisi yang secara ekonomis lebih bermanfaat bagi masyarakat bangsa.

Batasan ekonomi mengalami perkembangan melalui berbagai perbedaan pendapat mengikuti kepentingan, kemampuan pikir, serta lingkungan di masa itu. Perselisihan tersebut belum juga berhenti sampai saat ini, tetapi dalam perkembangan pertentangan itu terdapat perbedaan mendasar. Dahulu, perselisihan itu bersifat mencari "bentuk ekonomi" yang sesungguhnya, dan saat ini perbedaan pendapat di bidang ekonomi adalah berbentuk "bagaimana melayarkan bahtera perekonomian menuju tujuan, baik tujuan perorangan maupun bangsa". Dahulu benturan di antara ahli ekonomi adalah benturan paham, sedang saat ini adalah benturan "kepentingan". Tetapi yang jelas ekonomi telah mantap kedudukan dan bentuknya sebagai salah satu anggota dari bangunan ilmu pengetahuan yang besar. ${ }^{3}$

Banyak ilmuwan memberikan batasan

\footnotetext{
2 Sri Redjeki Hartono, Hukum Ekonomi Indonesia, 2007: Malang, Bayumedia Publishing, hlm. 113.

Tim Pengajar Mata Kuliah Hukum Ekonomi Fakultas Hukum Universitas Brawijaya,. Kumpulan Materi Kuliah Hukum Ekonomi. 2006 : Malang, hlm. 13.
} 
tentang ilmu ekonomi sebagai "salah satu cabang ilmu pengetahuan yang berdaya upaya untuk memberikan pengetahuan dan pengertian tentang gejala-gejala masyarakat yang timbul karena perbuatan manusia dalam usahanya untuk memenuhi kebutuhan atau untuk mencapai kemakmuran". Selain itu ilmu ekonomi juga didefinisikan sebagai "studi mengenai bagaimana orang menjatuhkan pilihan yang tepat untuk memanfaatkan sumber-sumber produktif yang langka dan terbatas guna menghasilkan berbagai barang serta mendistribusikannya kepada masyarakat yang mengkonsumsikannya".

Dari definisi di atas, dapat ditarik simpulan, bahwa pokok-pokok pikiran ilmu ekonomi sebenarnya adalah berkaitan dengan menghadapi masalah utama, yaitu masalah pemilihan karena faktor kelangkaan sumber daya, memproduksinya serta mendistribusikannya. Sehingga ilmu ekonomi berkaitan dengan pengaturan sumber daya, alokasi sumber daya yang efektif dan efisien, pengambilan keputusan di tengah-tengah kondisi kelangkaan. Kajian ekonomi ini terbatas pada usaha-usaha manusia untuk mencapai kemakmuran dengan menggunakan sumber daya ekonomi yang tersedia secara aman dan produktif. ${ }^{4}$ Maka dapat dipastikan pengaturan dalam penggunaan sumber daya ekonomi tersebut belum berorientasi pada bagaimana pencapaian keadilan dan kepastian dalam proses dan pencapaian tujuannya.

Akibat telah berkembangnya pranata hukum ekonomi yang sebelumnya tidak diatur dalam sistem hokum ekonomi Indonesia, seringkali menimbulkan konflik atau sengketa yang dalam hal ini lebih dikenal dengan istilah sengketa ekonomi. Hukum Ekonomi merupakan pranata hukum yang penting mengingat perkembangan ekonomi yang cukup pesat memerlukan pranata hukum

$4 \quad$ Rosyidi Suherman, Pengantar Teori Ekonomi, Pendekatan Kepada Teori Ekonomi Mikro dan Makro, 2006 : Jakarta, PT Raja Grafindo Persada, hlm. 42. yang pasti dan jelas untuk pengaturannya. Oleh karenanya hukum ekonomi sangatlah dibutuhkan dalam praktik perekonomian di Indonesia.

\section{B. Permasalahan}

Berdasarkan uraian di atas, permasalahan dalam penulisan ini adalah :

1. Bagaimanakah peran hukum dalam pembangunan ekonomi di Indonesia?

2. Bagaimanakah pembaharuan hukum ekonomi di Indonesia dalam pembangunan sistem hukum ekonomi nasional?

\section{Pembahasan}

\section{Peran Hukum Dalam Pembangunan Ekonomi Di Indonesia.}

Pada dasarnya hukum dan ekonomi ${ }^{5}$ adalah dua disiplin ilmu yang berbeda, dan memiliki paradigma dan tradisi keilmuan berbeda. Sejarah dan kelahiran yang berbeda antara kedua disiplin ilmu tersebut tidak merupakan penghalang bagi para ahli untuk menguasainya. Karena kedua ilmu ini memiliki titik singgung yang apabila dipahami dan dikelola dengan baik akan memberikan dampak signifikan terhadap peningkatan kesejahteraan umat manusia, sehingga tujuan awal mempelajari aspekaspek penting kedua disiplin ilmu ini sesungguhnya adalah untuk membangun

\footnotetext{
5 Ilmu ekonomi adalah bagian dari ilmu sosial. Istilah Ekonomi sendiri lahir di Yunani, dan berasal dari bahasa Yunani pula "oikos nomos" yang sebenarnya sulit diterjemahkan secara tepat. Barat menyederhanakannya menjadi "oikos" artinya rumah tangga, dan "nomos" yang berarti aturan, sehingga diartikan sebagai management of household or estate (tata laksana rumah tangga atau pemilikan). Dari hal yang dapat bermakna kecil (rumah tangga), istilah ini selanjutnya berkembang. Aristoteles (384-322 SM) yang dikenal sebagai the first economist mengembangkan "oikos nomos", dalam bukunya Politika dan Etika Nicomachea, disusun dasar-dasar teori nilai dan pertukaran, pembagian kerja, uang, suku bunga dan riba. Sehingga akhirnya ekonomi tidak sekedar mengatur yang kecil (tata laksana rumah tangga) tetapi juga rumah tangga yang besar (negara).
} 
sinergi yang tidak akan tercapai apabila hanya dalam kinerja satu bidang ilmu saja.

Persoalan-persoalan ekonomi selalu muncul dari penggunaan sumberdaya yang langka untuk memuaskan keinginan manusia yang tak terbatas dalam upaya meningkatkan kualitas hidupnya. Akibat kelangkaan, maka terjadi perebutan untuk menguasai sumberdaya yang langka tersebut. Perebutan menjadi penguasa atas sumber daya yang langka bisa menimbulkan persengketaan antar pelaku ekonomi bahkan bisa memicu perang baik antar daerah maupun antar negara.

Permasalahan ekonomi ini perlu diatur agar pemanfaatan sumber daya yang terbatas dapat berjalan dengan baik dengan prinsip - prinsip keadilan. Hukum ekonomi merupakan salah satu alat untuk mengatasi berbagi persoalan tersebut. Hukum ekonomi ini pun lebih lanjut mengatur kegiatan ekonomi, sehingga akan tampak peran hukum dalam kegiatan ekonomi ini.

Kegiatan ekonomi adalah setiap kegiatan manusia yang bertujuan untuk memenuhi kebutuhan hidupnya sehari-hari. Pada hakikatnya, kegiatan ekonomi adalah kegiatan menjalankan perusahaan, yaitu suatu kegiatan yang mengandung pengertian bahwa kegiatan yang dimaksud harus dilakukan dengan beberapa cara, antara lain secara terus menerus dan tidak terputus, secara terang-terangan sah, dan dilakukan dalam rangka memperoleh keuntungan untuk diri sendiri dan orang lain.

Tiap-tiap kelompok manusia mempunyai kebutuhan yang berbeda-beda tergantung tingkat kehidupan, budaya, pengetahuan dan sebagainya, demikian juga dengan cara untuk memenuhi kebutuhannya dan mempertahankan kelangsungan hidupnya, juga berbeda-beda pada setiap kelompok manusia. Hal ini sering menimbulkan benturan kepentingan antara kelompok yang satu dengan kelompok lainnya. Karena pada dasarnya kebutuhan yang diinginkannya walau seringkali akan menimbulkan kerugian bagi kelompok masyarakat lainnya.

Perkembangan kegiatan ekonomi pada umumnya selalu diikuti dengan maju dan berkembangnya nilai, etika, dan moral dari setiap pelakunya. Perkembangan etika bisnis atau etika dan moral yang melingkupi kegiatan ekonomi akan membawa kesejahteraan dan kemakmuran bersama. Etika dan moral tersebut akan melahirkan kebiasaan-kebiasaan tertentu yang akan menjadi aturan main dalam bisnis tertentu. ${ }^{6}$

Douglass C. North, seorang pemegang hadiah nobel tahun 1993 dalam bidang Ilmu Ekonomi, dalam essei yang berjudul Institutions and Economic Growth: An Historical Introduction mengatakan bahwa kunci dalam memahami peranan hukum dalam mengembangkan atau bahkan menekan pertumbuhan ekonomi terletak pada pemahaman konsep ekonomi"transaction cost" atau biaya-biaya transaksi. $^{7}$

Beberapa pakar ekonomi mengharapkan agar peran hukum diarahkan untuk menampung dinamika kegiatan ekonomi, dengan menciptakan kegiatan yang efisien dan produktif, dan mengandung daya prediktabilitas. Menurut Hernado de Soto, hukum yang baik adalah hukum yang menjamin bahwa kegiatan ekonomi dan sosial yang diaturnya dapat berjalan dengan efisien, sedangkan hukum yang buruk adalah hukum yang mengacaukan atau justru menghalangi kegiatan usaha, sehingga menjadi tidak efisien.

Dengan demikian, rangkaian kegiatan ekonomi memerlukan pengaturan yang baik agar kegiatan ekonomi tersebut dapat berjalan dengan efisien. Peraturan hukum

Sri Redjeki Hartono, Ibid., hlm. 118.

Adi Sulistiyono \& Muhammad Rustamaji, Hukum Ekonomi sebagai Panglima, Sidoarjo: 2009, Masmedia Buana Pustaka, hlm. 18-19.

Adi Sulistiyono \& Muhammad Rustamaji, Ibid.,hlm. 18 dan 58. 
yang diperlukan dalam ruang lingkup hukum ekonomi pada hakikatnya mengatur kegiatan ekonomi tersebut, baik yang meliputi ranah privat, maupun ranah publik. Pengaturan hukum yang dilakukan itu juga harus memperhatikan beberapa unsur agar hukum itu tidak menghambat kegiatan ekonomi. Hal ini sebagaimana yang diungkapkan oleh Burg's berdasarkan studi yang dilakukannya mengenai hukum dan pembangunan. Unsur-unsur tersebut meliputi stabilitas (stability), prediksi (predictability), keadilan (fairness), pendidikan (education), dan pengembangan khusus dari sarjana hukum (the special development abilities of the lawyer). Selanjutnya Burg's mengemukakan bahwa unsur pertama dan kedua ini merupakan persyaratan supaya sistem ekonomi berfungsi. Di sini "stabilitas" berfungsi untuk mengakomodasi dan menghindari kepentingan-kepentingan yang saling bersaing. Adapun prediksi merupakan kebutuhan untuk bisa memprediksi ketentuan-ketentuan yang berhubungan dengan ekonomi suatu negara. ${ }^{9}$ Dengan kata lain, prediksi ini harus mampu menunjukkan peran hukum dalam memberikan gambaran pasti di masa depan mengenai keadaan atau hubungan-hubungan yang dilakukan pada masa sekarang.

Konsep dasar sistem ekonomi yang dianut oleh Republik Indonesia dimana cabang-cabang produksi yang penting dan menguasai hajat hidup orang banyak dikuasai oleh negara dan digunakan sebesarbesarnya untuk kemakmuran rakyat. Negara juga mengakui hak milik pribadi, akan tetapi kepentingan umum harus berada diatas kepentingan pribadi dan golongan. Perekonomian yang akan disusun dalam bentuk ini adalah usaha bersama berdasarkan atas asas kekeluargaan. Usaha bersama atas dasar kekeluargaan ini dapat dilaksanakan dengan sistem koperasi dalam kehidupan

$9 \quad$ Adi Sulistiyono \& Muhammad Rustamaji, Ibid., hlm. 19- ekonomi.

Dalam sistem perekonomian yang menganut adanya keseimbangan antara perlindungan kepentingan pribadi dan perlindungan kepentingan nasional seringkali menimbulkan benturan. Benturan kepentingan ini terutama terjadi karena ketersediaan sumber daya manusia yang berkualitas dan modal yang terbatas dalam pengelolaan sumber-sumber ekonomi memaksa negara kita harus mendatangkan investor dari luar. Kepentingan investor kemudian dianalogikan sebagai kepentigan umum, oleh karena investor pada umumnya lebih bersifat kapitalisme dengan mencari keuntungan yang sebesar-besarnya. Dalam hal ini digunakan sebesar-besarnya untuk kemakmuran rakyat seringkali tidak dapat dipenuhi.

Jika Burg's mengemukakan peran hukum sebagai syarat berfungsinya sistem ekonomi, lain halnya dengan apa yang dikemukan oleh Prof. Dr. Sri Redjeki Hartono, S.H., M.Hum dalam bukunya Hukum Ekonomi Indonesia. Dalam bukunya itu, beliau mengemukakan bahwa pengaturan hukum dalam kegiatan ekonomi sangat penting dalam hal hubungan hukum para pihak. Karena itu hukum ekonomi dapat diartikan sebagai segala aturan yang berkaitan dengan berbagai aktivitas ekonomi, baik yang diatur oleh hukum, atau yang belum dan tidak diatur oleh hukum, mempunyai ruang lingkup pengertian yang luas meliputi segala persoalan berkaitan dengan hubungan antara hukum dan kegiatan-kegiatan ekonomi. ${ }^{10}$ Istilah hukum ekonomi dengan cakupan yang luas tersebut mencakup lingkup mikro dan makro, ekonomi pembangunan dan ekonomi sosial, ekonomi manajemen dan akuntansi.

Peran hukum sangat penting dalam kegiatan ekonomi yang berkelanjutan dan

\footnotetext{
10 Sri Redjeki Hartono, Hukum Ekonomi Indonesia, 2007:
} Malang, Bayumedia Publishing, hlm. 126. 
berdimensi sangat luas. Kemudian, beliau juga mengemukakan bahwa pengaturan hukum dalam kegiatan ekonomi mengatur semua aspek hukum yang meliputi ranah privat dan publik sesuai dengan peran dan otoritasnya pada suatu kegiatan sebagai berikut:

1. Perangkat peraturan pada ranah privat yang terdiri atas berbagai perundangan yang berada dalam dan di luar kodifikasi, meliputi:

a. Semua asas hukum yang berlaku bagi perbuatan-perbuatan hukum mendirikan perusahaan sesuai dengan kebutuhan;

b. Semua asas hukum yang meliputi semua jenis perjanjian dan pelaksanaan transaksi; dan

c. Ketentuan tentang dokumen.

2. Terdapat peragaman perangkat peraturan di bidang hukum administrasi yang mengatur persiapan pendirian perusahaan sebagai berikut:

a. Perangkat peraturan yang mengatur syarat-syarat dan prosedur mendirikan perusahaan;

b. Perangkat peraturan yang mengatur perizinan mengenai syarat pendirian dan prosedur pengajuan dan seterusnya;

c. Perangkat peraturan yang mengatur proses produksi dan mutu baku; dan

d. Perangkat peraturan pengepakan dan penyimpanan serta rentang waktu distribusi dan pemasaran.

3. Perangkat peraturan tentang lingkungan tempat usaha, tempat produksi, dan pengolahan limbah;

4. Perangkat pengaturan yang berhubungan dengan tenaga kerja, keselamatan kerja dan hak-hak para pekerja dan seterusnya, termasuk perlindungan terhadap tenaga kerja;

5. Perangkat pengaturan yang mengatur kewajiban-kewajiban pengusaha/pelaku ekonomi; dan

6. Perangkat peraturan yang mengatur kewajiban di bidang pajak dan lingkungan hidup.

Beberapa hal yang telah diuraikan di atas semakin menunjukkan bahwa hukum dan kegiatan ekonomi merupakan suatu kesatuan yang tidak dapat dipisahkan. Jika salah satu unsur di antara keduanya hilang, maka akan terjadi ketidakseimbangan dalam struktur organisasi masyarakat, terutama dalam bidang ekonomi. Adanya pengaturan hukum dalam kegiatan ekonomi memberikan ruang gerak yang lebih bebas namun terbatas. Artinya, kegiatan ekonomi dapat dilakukan dengan sebebas-bebasnya tanpa adanya keraguan dan ketakutan terjadi penyimpangan-penyimpangan dalam proses terjadinya kegiatan ekonomi karena hukum telah mengantisipasi dan mengcover hubungan-hubungan yang diprediksi akan terjadi di masa mendatang.

Pada awalnya hukum ekonomi adalah merupakan kajian hukum dagang sebagai suatu lingkup beberapa sub-bidang hukum dalam ranah hukum dagang yang selanjutnya mencapai bentuk optimal. Perkembangan hukum ekonomi pada tiap negara secara substansial dipengaruhi oleh sistem ekonomi, sejarah, sosial, politik dan budaya.

Di Belanda, hukum ekonomi dibagi menjadi 2 hal besar. Pertama adalah Hukum Ekonomi Sosial Makro (macro socialeconomisch recht) yang mengatur tentang keadaan ekonomi secara makro, yakni kepentingan ekonomi suatu negara (umum), dan kedua adalah Hukum Ekonomi Sosial Mikro (micro social-economisch recht), yang mengatur tentang ekonomi mikro, yaitu ekonomi perusahaan. ${ }^{11}$

\footnotetext{
11 Umar Farouk, Analisis Ekonomi Atas Perkembangan Hukum Bisnis Indonesia, http://mhugm,wikidot.com/ artikel:004
} 


\begin{abstract}
Dikaitkan dengan sistem hukum, perkembangan hukum ekonomi juga menunjukkan perbedaan yang cukup signifikan. Pada negara dengan sistem Anglo Saxon, eksistensi hukum ekonomi lebih mudah dipahami, karena pada sistem hukum kebiasaan, hukum ekonomi tumbuh dan berkembang bersama dengan perkembangan kebiasaan, sehingga lebih mudah diselenggarakan. Pada negara dengan sistem hukum eropa continental, eksistensi hukum harus dapat meyakinkan dan menunjukkan justifikasi serta hubungannya dengan perangkat hukum lainnya. Timbulnya kegiatan ekonomi ini membutuhkan kaidah atau pranata baru yang sulit dikategorikan ke dalam sistem hukum perdata dan dagang, sebagai hukum privat maupun publik. Perkembangan hubungan hukumnya pun tidak dapat diselesaikan berdasarkan pendekatan yang ada, kompleksitas permasalahan membutuhkan pendekatan baru.
\end{abstract}

Dalam memahami tentang hukum ekonomi, seringkali disamakan dengan istilah hukum bisnis. Keduanya memiliki keterkaitan yang sangat erat, tetapi istilah bisnis memiliki pengertian yang lebih sempit daripada ekonomi yang luas. Bisnis lebih tertuju pada usaha komersial dan interaksi antar pelakunya, yaitu berkaitan dengan ekonomi perusahaan/ekonomi mikro. Karakteristik bisnis terutama terletak pada tujuan pencapaian keuntungan. Kegiatan bisnis meliputi produksi, konsumsi dan penjualan barang-barang dan jasa-jasa untuk memperoleh laba. ${ }^{12}$

Hukum ekonomi muncul menggabungkan aspek privat dan publik dan mengintegrasikan berbagai pendekatan. Karakteristik hukum ekonomi berikut akan lebih menunjukkan perbedaannya dengan

12 Sanusi Bintang dan Dahlan, Pokok-Pokok Hukum Ekonomi dan Bisnis, 2000: Bandung, PT Citra Aditya Bakti, hlm. 32 hukum bisnis, walau memiliki persamaan sebagai perkembangan Hukum Dagang. Karakteristik umum hukum ekonomi adalah mencakup hukum publik dan privat, cakupannya lebih luas daripada hukum perdata dan hukum dagang, merupakan perpaduan antara hukum perdata, pidana, dagang, internasional, administrasi negara, tata negara, sehingga dapat dikatakan sebagai ilmu hukum yang bersifat interdisipliner, multidisipliner dan transnasional, mengatur secara rinci, menyeimbangkan kepentingan ekonomi dan kepentingan umum, dan dipengaruhi oleh sistem ekonomi. ${ }^{13}$

Hukum juga hadir sebagai penyeimbang hubungan antara para pelaku ekonomi. Sistem hukum harus dapat menjadi kekuatan yang memberikan keseimbangan di antara nilainilai yang bertentangan di dalam masyarakat. Sistem hukum ini memberikan "kesadaran akan keseimbangan" dalam usaha-usaha negara melakukan pembangunan ekonomi dan pembaharuan hukum ekonomi.

Negara kita tercinta Indonesia pada tahun 1998 mengalami krisis moneter, krisis ekonomi dan krisis kepercayaan yang segala dampak negatifnya telah dirasakan oleh seluruh masyarakat. Akibat dari kesalahankesalahan di dalam sektor bisnis yang turut menciptakan krisis tadi, kiranya telah tiba saatnya bagi para pelaku bisnis, para pembuat kebijakan, khususnya mereka yang berkecimpung dalam pengambilan keputusan, untuk memiliki "sense of risks" yang kuat agar tabiat menabrak risiko tidak lagi dilakukan. Pengambilan keputusan hendaknya tidak disebabkan oleh logikalogika sederhana, tetapi lebih karena hasil analisis yang tajam dan mendalam.

Tragedi krisis moneter, krisis ekonomi berlanjut pada krisis kepercayaan yang melanda Indonesia pada tahun 1998 karena kesalahan-kesalahan yang dilakukan oleh

13 Todung Mulya Lubis, Hukum dan Ekonomi, 1992: Jakarta, Pustaka Sinar Harapan, hlm. 21. 
para pengambil keputusan yang dalam hal ini adalah pemimpin atau manajer baik pimpinan perusahaan juga pemimpin dalam jalur pemerintahan. Semuanya dilakukan atas dasar persaingan dalam bisnis walaupun harus berisiko tinggi. Hal ini juga merupakan arogansi para pelaku bisnis yang sama sekali tidak mendasarkan pada tujuan untuk memajukan kesejahteraan seluruh rakyat Indonesia, namun monopoli ekonomi konglomerat dengan fakta yang ada tentang betapa merajalelanya perusahaan-perusahaan besar yang jelasjelas menunjukkan tentang keadaan ekonomi Indonesia yang tirani dan tidak demokratis.

Fenomena segelintir perusahaanperusahaan besar yang menguasai lebih dan separuh kekayaan nasional merefleksikan tidak tumbuhnya demokrasi ekonomi secara makro. Dimana negara tidak dapat menjamin pemerataan sumber-sumber ekonomi dan penghidupan yang layak bagi warga negaranya. Prinsip usaha bersama atas dasar kekeluargaan ternyata hanya dalam teks konstitusional semata sedangkan dalam implementasinya tidak dapat diterapkan. Dalam hal ini prinsip-prinsip demokrasi seyogyanya diterapkan dalam kehidupan intern korporasi.

Dan segi hukum perusahaan, usaha konglomerat tidak lain dari kumpulan perusahaan berbentuk perseroan terbatas yang umumnya dengan integrasi oleh suatu perusahaan holding, yang biasanya juga berbentuk perseroan terbatas. Karena itu kaidah hukum tentang perseroan terbatas yang terdapat dalam KUHD mulai dari Pasal 36 sampai dengan pasal 56 dan termasuk Pasal 56 dahulunya berlaku, diganti dengan Undang-Undang No. 1 Tahun 1995 tentang Perseroan Terbatas. Namun dalam tataran prakteknya Undang-Undang ini juga menumbuh kembangkan korporasi, karena pada prinsipnya individualisme dan kapitalisme lebih diutamakan dalam pendirian perseroan terbatas. Perseroan terbatas adalah kumpulan modal (acumulasi capital) bukan kumpulan orang sebagaimana diharapkan oleh undang-undang dasar dimana perekonomian adalah usaha bersama yang diimplementasikan dengan kumpulan orang-orang atau Koperasi.

Dilihat dan segi kepemilikannya, disamping merupakan perusahaan swasta, ada juga konglomerat yang merupakan Badan Usaha Milik Negara (BUMN) tetapi belum pernah dijumpai konglomerat dalam bentuk koperasi, walaupun kemungkinan untuk itu tentunya terbuka. Undang-Undang Dasar 1945 menjamin eksistensi BUMN dan koperasi dan sesungguhnya bahkan kurang memberi tempat kepada sektor swasta. Secara praktis, terjadi diferensiasi yang relatif longgar terhadap bidang bisnis yang boleh dimasuki oleh masing-masing konglomerat ekonomi tersebut, yaitu BUMN, Koperasi dan sektor swasta.

Bidang-bidang yang sangat terpaut dengan kepentingan umum, seperti perminyakan, gas bumi, pelistrikan, kereta api, air minum, merupakan segmen bisnis untuk BUMN, ini sebagai konsekuensi logis dari eksistensi Pasal 33 ayat 2 dan 33 ayat 3 Undang-Undang Dasar 1945, yakni sebagai pengejawantahan dan kata "dikuasai" oleh negara yang terdapat dalam pasal tersebut. Selanjutnya Pasal 33 ayat 2 Undang-Undang Dasar 1945 mengisyaratkan penguasaan negara secara langsung terhadap cabangcabang produksi yang penting bagi negara dan menguasai hajat hidup orang banyak. Sedangkan Pasal 33 ayat 3 memberi kekuasaan pada negara untuk secara langsung menguasai kegiatan-kegiatan yang terkait dengan pengolahan/pengelolaan sumber daya bumi, air dan kekayaan alam yang terkandung didalamnya. Karena itu seyogyanya pihak selain BUMN tidak dibenarkan beroperasi di bidang-bidang seperti ini. Atau jikapun mereka beroperasi, haruslah dilakukan dengan pertimbangan kesejahteraan rakyat banyak oleh pemerintah sebagai pihak yang 
berwenang menguasai. Dengan pertimbangan kesejahteraan dan keadilan tersebut, negara tidak melepaskan kepemilikan, baik secara yuridis maupun secara konseptual. Misalnya hutan merupakan salah satu contoh kekayaan alam, maka mestinya pihak swasta tidak perlu diberikan HPH atau bentukbentuk penguasaan lain yang sangat meluas kekuasaannya, sedemikian luasnya sehingga pemerintah tak hanya tinggal sebagai pihak "pemberi lisensi" semata-mata. Lain halnya jika HPH tersebut misalnya hanya diberikan kepada BUMN.

Menindaklanjuti perintah Presiden Jokowi, Menteri Koordinator Bidang Perekonomian (Menko Perekonomian) Darmin Nasution pun membentuk tim khusus yang kemudian melakukan koordinasi dengan Badan Koordinasi Penanaman Modal (BKPM) dan beberapa kementerian dan lembaga terkait. Sejumlah langkah perbaikan itu pun dituangkan dalam Paket Kebijakan Ekonomi mulai dari jilid 1 hingga jilid 12, paket ekonomi jilid 12 yang diumumkan Presiden Jokowi sendiri pada Kamis, 28 April 2016, di Istana Kepresidenan, Jakarta. "Ini paket yang besar dan penting dengan cakupan yang luas," ujar Menko Perekonomian Darmin Nasution, dikutip dalam Siaran persnya, Kamis 28 April 2016.

Penetapan paket ini berawal dari penetapan 9 indikator tingkat kemudahan berusaha oleh Bank Dunia. Masing-masing adalah :

1. Memulai Usaha (Starting Business).

2. Perizinan terkait Pendirian Bangunan (Dealing with Construction Permit).

3. Pembayaran Pajak (Paying Taxes)

4. Akses Perkreditan (Getting Credit)

5. Penegakan Kontrak (Enforcing Contract)

6. Penyambungan Listrik (Getting Electricity)

7. Perdagangan Lintas Negara (Trading
Across Borders)

8. Penyelesaian Perkara Kepailitan (Resolving Insolvency) dan

9. Perlindungan Terhadap Investor Minoritas (Protecting Minority Investors).

Sebagai upaya untuk menstabilkan kondisi ekonomi Indonesia, pemerintahan Jokowi-JK meluncurkan berbagai program guna menstimulasi pertumbuhan ekonomi yang lambat di awal pemerintahan mereka. Yang paling populer saat ini adalah Paket kebijakan Ekonomi Berjilid, karena paket ini terdiri dari beberapa jilid yang memiliki fokus yang berbeda untuk menyasar beberapa target yang diduga dapat merangsang pergerakan ekonomi.

Sistem perekonomian adalah sistem yang digunakan oleh suatu negara untuk mengalokasikan sumber daya yang dimilikinya baik kepada individu maupun organisasi di negara tersebut. Perbedaan mendasar antara sebuah sistem ekonomi dengan sistem ekonomi lainnya adalah bagaimana cara sistem itu mengatur faktor produksinya. Dalam beberapa sistem, seorang individu boleh memiliki semua faktor produksi. Sementara dalam sistem lainnya, semua faktor tersebut di pegang oleh Pemerintah. Kebanyakan sistem ekonomi di dunia berada di antara dua sistem ekstrim tersebut.

Sistem ekonomi Indonesia adalah sistem ekonomi yang berorientasi kepada Ketuhanan Yang Maha Esa (berlakunya etik dan moral agama, bukan materialisme); Kemanusiaan yang adil dan beradab (tidak mengenal pemerasan atau eksploitasi); Persatuan Indonesia (berlakunya kebersamaan, asas kekeluargaan, sosio-nasionalisme dan sosiodemokrasi dalam ekonomi); Kerakyatan (mengutamakan kehidupan ekonomi rakyat dan hajat hidup orang banyak); serta Keadilan Sosial (persamaan/emansipasi, kemakmuran masyarakat yang utama, 
bukan kemakmuran orang-seorang).

Perkembangan Pemikiran Sistem Ekonomi Indonesia, seperti yang kita ketahui bahwa yang menentukan bentuk suatu sistem ekonomi kecuali dasar falsafah negara yang dijunjung tinggi, maka yang dijadikan kriteria adalah lembaga-lembaga, khususnya lembaga ekonomi yang menjadi perwujudan atau realisasi falsafah tersebut.

Pergulatan pemikiran tentang sistim ekonomi apa yang sebaiknya di diterapkan Indonesia telah dimulai sejak Indonesia belum mencapai kemerdekaannya. Sampai sekarang pergulatan pemikiran tersebut masih terus berlangsung, hal ini tecermin dari perkembangan pemikiran tentang Sistem Ekonomi Pancasila (SEP). Menurut SriEdi Suwasono (1985), pergulatan pemikiran tentang SEP pada hakikatnya merupakan dinamika penafsiran tentang pasal-pasal ekonomi dalam UUD 1945.

Pasal Ekonomi Dalam UUD 1945, Pasal 33 UUD 1945, yang dimaksud dengan cabang-cabang produksi yang menguasai hajat hidup orang banyak adalah barang dan jasa yang vital bagi kehidupan manusia, dan tersedia dalam jumlah yang terbatas. Tinjauan terhadap vital tidaknya suatu barang tertentu terus mengalami perubahan sesuai dengan dinamika pertumbuhan ekonomi, peningkatan taraf hidup dan peningkatan permintaan.

Dengan demikian penafsiran pasalpasal di ataslah yang banyak mendominasi pemikiran SEP. Pemikiran tentang SEP, sudah banyak, namun ada beberapa yang perlu dibahas secara rinci karena mereka merupakan faunding father dan juga tokohtokoh ekonomi yang ikut mewarnai sistem ekonomi kita, diantaranya :

\section{Pemikiran Mohammad Hatta (Bung Hatta)}

Bung Hatta selain sebagai tokoh Proklamator bangsa Indonesia, juga dikenal sebagai perumus pasal 33 UUD 1945. Bung
Hatta menyusun pasal 33 didasari pada pengalaman pahit bangsa Indonesia yang selama berabad-abad dijajah oleh bangsa asing yang menganut sitem ekonomi liberal-kapitalistik. Penerapan sistem ini di Indonesia telah menimbulkan kesengsaraan dan kemelaratan, oleh karena itu menurut Bung Hatta sistem ekonomi yang baik untuk diterapkan di Indonesia harus berasakan kekeluargaan.

\section{Pemikiran Wipolo}

Pemikiran Wipolo disampaikan pada perdebatan dengan Wijoyo Nitisastro tentang pasal 38 UUDS (pasal ini identik dengan pasal 33 UUD 1945), 23 september 1955. Menurut Wilopo, pasal 33 memiliki arti SEP sangat menolak sistem liberal, karena itu SEP juga menolak sector swasta yang merupakan penggerak utama sistem ekonomi liberal-kapitalistik

\section{Pemikiran Wijoyo Nitisastro}

Pemikiran Wijoyo Nitisastro ini merupakan tanggapan terhadap pemikiran Wilopo. Menurut Wijoyo Nitisastro, pasal 33 UUD 1945 sangat ditafsirkan sebagai penolakan terhadap sektor swasta.

\section{Pemikiran Mubyarto}

Menurut Mubyarto, SEP adalah sistem ekonomi yang bukan kapitalis dan juga sosialis. Salah satu perbedaan SEP dengan kapitalis atau sosialis adalah pandangan tentang manusia. Dalam sistem kapitalis atau sosialis, manusia dipandang sebagai mahluk rasional yang memiliki kecenderungan untuk memenuhi kebutuhan akan materi saja.

\section{Pemikiran Emil Salim}

Konsep Emil Salim tentang SEP sangat sederhana, yaitu sistem ekonomi pasar dengan perencanaan. Menurut Emil Salim, di dalam sistem tersebutlah tercapai keseimbangan antara sistem komando dengan sistem pasar. "lazimnya suatu sistem ekonomi bergantung erat dengan paham-ideologi yang dianut suatu Negara. Sumitro Djojohadikusumo 
dalam pidatonya di hadapan School of Advanced.

\section{Pembaharuan Hukum Ekonomi Di Indonesia.}

Pembaharuan hukum yaitu menyusun tata hukum agar disesuaikan dengan perubahan masyarakat. Pembaharuan hukum juga merupakan upaya sadar yang dilakukan untuk merubah suatu kondisi dari suatu tingkat yang dianggap kurang baik ke kondisi baru pada tingkat kualiatas yang dianggap baik atau paling baik.

Pembaharuan hukum sebenarnya mengandung makna yang luas mencakup system hukum. Menurut Friedman, "system hukumterdiriatasstrukturhukum(structure), substansi/materi hukum(substance) dan budaya hukum (legal culture). Perubahan yang dilakukan dan memiliki arti yang positif akan menciptakan hukum baru yang sesuai dengan kondisi pembangunan dan nilai-nilai hukum masyarakat.

Pembaharuan hukum merupakan prioritas utama, terlebih jika Negara dimaksud merupakan Negara yang baru merdeka dari penjajahan bangsa/Negara lain. Oleh karena itu, dinegara-negara berkembang pembaharuan hukum senantiasa mengesankan adanya peranan ganda, yaitu :

1. Merupakan upaya untuk melepaskan diri dan lingkaran struktur kolonial, upaya tersebut terdiri atas penghapusan, penggantian dan penyesuaian ketentuan hukum warisan kolonial guna memenuhi tuntutan masyarakat kolonial.

2. Pembaharuan hukum berperan pula dalam mendorong proses pembangunan ekonomi yang memang diperlukan dalam rangka mengejar ketertinggalan dari Negara maju dan yang lebih penting adalah demi peningkatan kesejahteraan masyarakat warga Negara.
Penyelundupan hukum sering terjadi dengan cara penyerahan kewenangan dan atau kepemilikan perusahaan konglomerasi kepada orang lain dengan alasan-alasan:

1. Pihak yang berkepentingan sendiri tidak punya waktu untuk melakukannya sendiri.

2. Pihak yang berkepentingan sendiri tidak cukup banyak skill untuk melakukannya sendiri.

3. Pihak yang berkepentingan sendiri tidak cukup berbuat secara yuridis, misalnya dia belum dewasa atau terganggu pikirannya.

4. Pihak yang berkepentingan sendiri tidak berwenang melakukannya karena dilarang oleh hukum.

Penyelundupan hukum dapat terjadi terhadapkemungkinanyangterakhirtersebut, yakni dalam hal diangkatnya seorang trustee nominee untuk melakukan suatu perbuatan karena pihak yang berkepentingan sendiri tidak berwenang melakukan perbuatan tersebut berhubung adanya larangan secara hukum. Dengan penyelundupan hukum tersebut, maka seseorang memang tidak berbuat sendiri atas suatu perbuatan karena memang dilarang, tetapi larangan tersebut dapat diselundupinya dengan mengangkat seorang lain untuk melakukan perbuatan tersebut untuk kepentingan pihak yang mengangkatnya. Sehingga seseorang yang sebenarnya dilarang oleh hukum untuk mendapatkan fasilitas tertentu, akhirnya juga dapat menikmati fasilitas tersebut lewat pengangkatan seorang trustee, fasilitas mana dinikmatinya tidak ubahnya seperti dinikmati oleh pihak yang memang oleh hukum diberi wewenang untuk itu.

Melihat perkembangan sosial-ekonomipolitik saat ini, akhirnya kita pun harus bersikap realisitis bahwa proses reformasi hukum terutama hukum pembaharuan ekonomi senantiasa sulit dan lama. Kunci penting dari reformasi hukum pembaharuan 
ekonomi Indonesia sebenarnya adalah mengembalikan sistem perekonomian kepada amanat konstitusional dimana perekonomian disusun sebagai usaha bersama atas asas kekeluargaan dan negara mempunyai hak menguasai bagi cabang-cabang produksi yang penting serta menguasai hajat hidup orang banyak dan digunakan sebesarbesarnya untuk kemakmuran rakyat.

Sudah menjadi satu keniscayaan, bahwa pembangunan ekonomi di suatu negara, secara khusus negara berkembang, hukum memiliki peranan yang besar untuk turut memberi peluang pembangunan ekonomi. Pelaksanaan roda pemerintahan dengan demokratis dengan menggunakan hukum sebagai instrumen untuk merencanakan dan melaksanakan program pembangunan yang komprehensif, akan membawa negara ini menuju masyarakat dengan tingkat kesejahteraan yang di cita-citakan. Dalam upaya memberikan masukan yang relevan sebagai bahan dasar untuk melakukan pembangunan hukum ekonomi, perlu diketahui peran hukum terhadap bidang ekonomi. Dengan langkah ini akan bisa diketahui tuntutan bidang ekonomi pada bidang hukum yang bisa dijadikan masukan yang bermanfaat untuk menunjang pertumbuhan ekonomi.

\section{Sistem Ekonomi Pancasila (SEP)}

Sistem menurut Chester I. Bernard, adalah suatu kesatuan yang terpadu secara holistik, yang di dalamnya terdiri atas bagian-bagian dan masing-masing bagian memiliki ciri dan batas tersendiri. Suatu sistem pada dasarnya adalah "organisasi besar" yang menjalin berbagai subjek atau objek serta perangkat kelembagaan dalam suatu tatanan tertentu. Subjek atau objek pembentuk sebuah sistem dapat berupa orang-orang atau masyarakat, untuk suatu sistem sosial atau sistem kemasyarakatan dapat berupa makhluk-makhluk hidup dan benda alam, untuk suatu sistem kehidupan atau kumpulan fakta, dan untuk sistem informasi atau bahkan kombinasi dari subjek-subjek tersebut. ${ }^{14}$

Ekonomi merupakan salah satu ilmu sosial yang mempelajari aktivitas manusia yang berhubungan dengan produksi, distribusi, pertukaran, dan konsumsi barangdan jasa. Istilah "ekonomi" sendiri berasal dari kata Yunani oikos yang berarti "keluarga, rumah tangga" dan nomos, atau "peraturan, aturan, hukum," dan secara garis besar diartikan sebagai "aturan rumah tangga" atau "manajemen rumah tangga." Sementara yang dimaksud dengan ahli ekonomi atau ekonom adalah orang menggunakan konsep ekonomi dan data dalam bekerja.

Pancasila adalah ideologi dasar bagi negara Indonesia. Nama ini terdiri dari dua kata dari Sansekerta: panca berarti lima dan sila berarti prinsip atau asas. Pancasila merupakan rumusan dan pedoman kehidupan berbangsa dan bernegara bagi seluruh rakyat Indonesia. Lima sendi utama penyusun Pancasila adalah Ketuhanan Yang Maha Esa, kemanusiaan yang adil dan beradab, persatuan Indonesia, kerakyatan yang dipimpin oleh hikmat kebijaksanaan dalam permusyawaratan/perwakilan, dan keadilan sosial bagi seluruh rakyat Indonesia, dan tercantum pada paragraf ke-4 Preambule (Pembukaan) Undang-undang Dasar 1945.

Sistem Ekonomi Pancasila adalah ekonomi yang dijiwai oleh ideology pancasila, yaitu system ekonomi yang merupakan usaha bersama yang berdasarkan kekeluargaan dan kegotong-royongan nasional. Kegotongroyongan nasional, bukan hanya kegotongroyongan di pedesaan, di rukun kampong, tetapi kegotong - royongan pada tingkat

\footnotetext{
$14 \quad$ Di kutip dari paper yang dibuat oleh Hernawati Fakultas Ilmu Sosial dan Ilmu Politik: tahun 2006, Universitas Haluoleo.
} 
nasional. ${ }^{15}$ Polemik tentang system ekonomi Indonesia sekitar tahun 1980-1981 berkisar kepada gagasan Mubyarto mengenai Sistem Ekonomi Pancasila (SEP). Sebutan SEP sebenarnya telah dilontarkan lebih dulu oleh Emil Salim dalam suatu artikel pada harian Kompas tanggal 30 juni 1966. Dikalangan para pakar terdapat dua cara pandang terhadap SEP. Pertama, jalur yuridis formal, yang berangkat dari keyakinan bahwa landasan hukum SEP adalah pasal 33 UUD 1945, yang dilatarbelakangi oleh jiwa pembukaan UUD 1945 dan dilengkapi oleh pasal 23,27 ayat 2,34 , serta penjelasan pasal 2 UUD 1945. Jalur kedua adalah jalur orientasi, yang menghubungkan sila-sila dalam Pancasila.

Pada penulisan ini, penulis akan menyampaikan pemikiran-pemikiran ekonom pancasila serta menyoroti dua topik utama yang terkait dengan Sistem Ekonomi Pancasila, yaitu moral ekonomi pancasila, dan landasan pikir sistem ekonomi pancasila.

\section{a. PEMIKIRAN EKONOMI}

\section{1) МОН. НАТТА.}

Pemikiran ekonomi Bung Hatta (Hattanomics) dapat didekati melalui beberapa pendekatan. Pertama, melalui kerangka berpikir ekonomi Bung Hatta. Dilihat dari sudut itu, kerangka berpikir ekonomi Bung Hatta dalam garis besarnya tersusun berdasarkan tiga kategori berikut: teori ekonomi, politik ekonomi, dan politik perekonomian.

Mengenai teori ekonomi, Bung Hatta dengan tegas menyatakan bahwa penjelasan teori ekonomi hanya mengandung kebenaran sejauh diterapkan pada dirinya sendiri. Artinya, sejauh diuji berdasarkan asumsinya, kebenaran teori ekonomi bersifat mutlak. Tetapi karena asumsi-asumsi teori ekonomi itu tidak ditemukan dalam realitas ekonomi,

15 Lihat Ekonomi pancasila : Gagasan dan Kemungkinan/ mubyarto: 1987, Jakarta, LP3ES, Bab II. penjelasan teori ekonomi itu harus dilihat hanya sebagai alat bantu dalam memahami realitas ekonomi. Agar pemakaian teori ekonomi sebagai alat bantu untuk memahami realitas ekonomi itu tidak menggiring pemakainya pada suatu kesimpulan yang salah, selanjutnya diperlukan apa yang oleh Bung Hatta disebut sebagai politik ekonomi. Sebagai suatu siasat untuk melaksanakan teori ekonomi, politik ekonomi harus memperhatikan keberadaan faktor-faktor non ekonomi. Berbeda dari politik ekonomi, politik perekonomian adalah keputusan politik yang didasarkan atas pertimbangan ideologi politik negara, dan paham kemasyarakatan. Bung Hatta meletakkan ideologi pada kedudukan yang sangat tinggi. Di bawah ideologi terletak realitas ekonomi. Sedangkan teori ekonomi terletak di urutan terbawah.

Sejalan dengan itu, pendekatan kedua yang perlu ditempuh untuk memahami pemikiran ekonomi Bung Hatta adalah dengan menelusuri ideologi yang mendasari pemikiran ekonominya. Dalam rangka itu, perlu diketahui, selain dikenal sebagai penganjur sosialisme, Bung Hatta juga dikenal sebagai penganjur demokrasi yang konsisten. Hanya saja, berbeda dari paham demokrasi yang saat ini banyak dianut di Indonesia, paham demokrasi yang dianut Bung Hatta tidak hanya berlaku dalam bidang politik, tetapi berlaku pula dalam bidang ekonomi. Dengan titik tolak seperti itu, setiap upaya untuk memahami pemikiran ekonomi Bung Hatta, harus dimulai dengan memahami prinsip demokrasi ekonomi yang menjadi dasar pemikiran ekonominya.

Hal ini penting, sebab demokrasi ekonomi bagi Bung Hatta tidak hanya dipandang sebagai sebuah proses pengambilan keputusan sebagaimana terjadi dalam bidang politik, tetapi sekaligus sebagai dasar (struktur) untuk mewujudkan keadilan sosial. Sebagaimana dikemukakan oleh penjelasan pasal 33 UUD 1945. Prioritas utama politik 
perekonomian yang demokratis adalah diletakkannya kemakmuran masyarakat di atas kemakmuran orang seorang. Di dalam berbagai tulisannya, Mohammad Hatta menyatakan prinsip non-kooperatif yang tertuang dalam Manifesto Politik 1925. Dari pernyataan Perhimpunan Indonesia tahun 1923 dan tahun 1925, dapat ditarik hakikat manifesto :

a) Perjuangan memperoleh otonomi, mencapai kemerdekaan Indonesia,

b) Pemerintahan yang dipegang dan dipilih oleh bangsa Indonesia sendiri,

c) Kesatuan sebagai syarat perjuangan mencapai tujuan,

d) Menolak bantuan dari pihak penjajah atau pihak lain manapun.

Dari tulisan monumental Mohammad Hatta Ke Arah Indonesia Merdeka (1932) mengenai faham kebangsaan dan kerakyatan, sekali lagi Mohammad Hatta menegaskan bahwa:

"...Asas Kerakyatan mengandung arti, bahwa kedaulatan ada pada rakyat. Segala Hukum (Recht, peraturan-peraturan negeri) haruslah bersandar pada perasaan Keadilan dan Kebenaran yang hidup dalam hati rakyat yang banyak, dan aturan penghidupan harus sempurna dan berbahagia bagi rakyat kalau ia beralasan kedaulatan rakyat. Asas kedaulatan rakyat inilah yang menjadi sendi pengakuan oleh segala jenis manusia yang beradap, bahwa tiap-tiap bangsa mempunyai hak untuk menentukan nasib sendiri..."

Kemudian Mohammad Hatta menegaskan pula:

"...Supaya tercapai suatu masyarakat yang berdasar Keadilan dan Kebenaran, haruslah rakyat insaf akan haknya dan harga dirinya. Kemudian haruslah ia berhak menentukan nasibnya sendiri dan perihal bagaimana ia mesti hidup dan bergaul. Pendeknya, cara mengatur pemerintahan negeri, cara menyusun perekonomian negeri semuanya harus diputuskan oleh rakyat dengan mufakat..."

\section{2) MUBYARTO.}

Mubyarto lahir di Sleman, 3 September 1938 dan meninggal di Rumah Sakit Umum Dr Sardjito Yogyakarta, Selasa 24 Mei 2005 pukul 13.49. Masa kecilnya hingga sarjana muda dihabiskan di Yogyakarta. Selepas dari UGM, Mubyarto melanjutkan pendidikan master di Universitas Vanderbilt dan program doktor di Universitas Iowa, Amerika Serikat, dengan disertasi berjudul Elastisitas Surplus Beras yang Dapat Dipasarkan di JawaMadura, 1965.

Pada tahun 1987-1999, ia menjadi anggota MPR. Selain itu, dia juga menjabat sebagai dosen di Fakultas Ekonomi UGM (1959-2003) serta sebagai Kepala Pusat Penelitian Pembangunan Pedesaan dan Kawasan (P3PK) UGM tahun 19831994. Di struktur pemerintahan pusat, Mubyarto pernah menjabat sebagai staf ahli di kementerian, yaitu penasihat Menteri Perdagangan pada tahun 1968-1971, asisten Menteri Badan Perencanaan Pembangunan Nasional (1993-1998), dan staf ahli Menteri Koordinator Bidang Perekonomian, Keuangan, dan Industri pada tahun yang sama. Sejak tahun 2002, dia adalah Kepala Pustep UGM.

Dalam bukunya, Apa \& Siapa: Sejumlah Orang Indonesia 1985-1986, konsep Ekonomi Pancasila yang dikembangkan Mubyarto sempat ditertawakan sejumlah kalangan. Konsepnya itu dianggap berbau slogan, namun ia menilainya sebagai hal yang wajar karena merupakan hal yang baru. Di masa Orde Baru paham Ekonomi Pancasila yang diusungnya dipandang sebelah mata oleh para ekonom Indonesia kala itu yang 
kebanyakan berdomisili di FE UI dan juga beberapa rekan beliau di FE UGM. Pandangannya dianggap sudah kadaluarsa mengingat sistem ekonomi Indonesia kala itu cenderung mengarah pada ekonomi liberal. Ketika krisis ekonomi melanda Indonesia di pertengahan 1997 Mubyarto menampik anggapan banyak ekonom yang berkata bahwa ekonomi Indonesia hampir mati. Beliau berpendapat melalui kacamata ekonomi kerakyatan bahwa sebenarnya ekonomi rakyat kala itu tidaklah mati hanya sedikit kaget saja untuk kemudian berjalan kembali tanpa ada istilah mati. Yang mati menurut beliau adalah ekonomi konglomerat yang memang seharusnya, menurut beliau, jangan diperbaiki. Pak Muby menyebut ekonomi mikro, ekonomi kerakyatan justru semakin berkembang di tengah krisis yang dialami para konglomerat.

Krisis Ekonomi menurut pandangan Mubyarto hanyalah penyederhanaan krisis multidimensional di Indonesia. Pak Muby memandang krisis ekonomi yang terjadi disebabkan karena pembangunan ekonomi di Indonesia telah meninggalkan dan mengabaikan dua unsur penting manusia Pancasila, yaitu moral dan sosial. Ekonomi Pancasila atau Pancasila Kerakyatan bukanlah komunis seperti yang dianggap oleh sebagian orang. Sebagai seorang ekonom Pak Muby berpendapat sebagai berikut: Demikian, berbeda dengan pandangan pakar-pakar ekonomi arus utama (main stream), kerusakan ekonomi yang dialami sektor modern/ konglomerat tidak perlu diratapi, dan kita tidak perlu mati-matian memulihkan kondisi ekonomi pra-krisis yang sangat timpang.

Ekonomi kerakyatan adalah sistem ekonomi yang demokratis, menunjuk pada asas ke-4 Pancasila, kerakyatan yang dipimpin oleh hikmat kebijaksanaan dalam permusyawaratan / perwakilan, dimana ekonomi rakyat mendapat dukungan pemihakan yang sungguh-sungguh dari pemerintah. Bahwa sejauh ini pakar-pakar ekonomi arus utama menolak konsep ekonomi kerakyatan, bahkan juga ekonomi kekeluargaan, yang hendak digusur dari pasal 33 UUD 1945, adalah karena mereka secara a priori menganggap ekonomi kerakyatan bukan sistem ekonomi pasar, tetapi dituduh sebagai sistem ekonomi ${ }^{3}$ sosialis-komunis' ala Orde Lama 1959-1966. Pandangan dan pemihakan mereka pada konglomerat yang liberal-kapitalistik memang amat sulit diubah lebih-lebih setelah (istilah mereka) 'Uni Sovyet pun kapok dengan sosialisme, dan RRC juga sudah menjadi kapitalis'. Sudah pasti mereka 'keblinger' karena paham sosialisme tidak pernah mati, dan ekonomi RRC tumbuh cepat bukan karena meninggalkan paham sosialisme tetapi karena amat berkembangnya ekonomi rakyat. Ekonomi Indonesia akan tumbuh cepat seperti ekonomi RRC jika mampu mengalahkan virus korupsi yang tumbuh subur sejak awal gerakan reformasi yang telah benar-benar melenceng.

Aturan main sistem ekonomi Pancasila yang lebih ditekankan pada sila ke-4 Kerakyatan (yang dipimpin oleh hikmat kebijaksanaan dalam permusyawaratan / perwakilan) menjadi slogan baru yang diperjuangkan sejak reformasi. Melalui gerakan reformasi banyak kalangan berharap hukum dan moral dapat dijadikan landasan pikir dan landasan kerja. Sistem ekonomi kerakyatan adalah sistem ekonomi yang memihak pada dan melindungi kepentingan ekonomi rakyat melalui upaya-upaya dan program-program pemberdayaan ekonomi rakyat.

\section{b. MORAL EKONOMI PANCASILA}

Moral Ekonomi Pancasila merupakan sebagai kesatuan ukuran, atau normanorma yang mengatur pola berpikir dan pola bertindak dari pelaku-pelaku ekonomi dalam Sistem Ekonomi Pancasiala. Sistem Ekonomi 
Pancasila masih harus diperjuangkan, masih harus digarap, masih harus diolah dikembangkan, dan ditumbuhkan. Lima ciri khas Sistem Ekonomi Pancasila sebagimana bisa diserap dari UUD 45 pasal 33, bahkan dari keseluruhan jiwa pancasila itu sendiri, antara lain :

1) Dalam Sistem Ekonomi Pancasila, koperasi merupakan soku guru perekonomian. Koperasi ialah salah satu bentuk yang paling konkrit dari usaha bersama. Dalam UUD 1945 pasal 33, dikatakan, perekonomian disusun sebagai usaha bersama berdasarkan atas asas kekeluargaan.

2) Perekonomian digerakan oleh rangsangan-rangsangan ekonomi, sosial, dan moral. Walaupun telah dikatakan, bahwa masalah ekonomi menyangkut masalah materi, namun hal itu tidaklah berarti bahwa materi itu tidak ada hubungannya dengan moral dan sosial. Jika kita juga memperhatikan masalah moral dan sosial di samping ekonomi, maka hal ituberarti kebijaksanaan dan tindakan ekonomi kita akan lain, dibandingkan apabila yang dikejar hanyalah rangsangan ekonomi saja.

3) Ada hubungannya dengan sila pertama Ketuhanan Yang Maha Esa, adalah kehendak yang kuat dari seluruh masyarakat ke arah keadaan kemerataan sosial, egalitarisme. Ada suatu keinginan dalam masyarakat ekonomi kapitalis, bahwa yang penting ${ }^{3}$ saya untung. Kamu melarat, go to hell', tetapi dalam Ekonomi Pancasila harus tidak ada perasaan seperti itu. Rasa solidaritas sosial menjiwai para pelaku di dalam tindaktanduknya. Hal ini berkali-kali di tekankan oleh Presiden Soeharto. Solidaritas social harus merupakan jiwa masyarakat Pancasila.

4) Ada kaitannya dengan sila Persatuan Indonesia. Prioritas kebijakan ekonomi ialah penciptaan perekonomian nasional yang tangguh, yang berarti bahwa nasionalisme menjiwai tiap kebijaksanaan ekonomi.

5) Dalam sistem perekonomian Pancasila, harus tegas dan jelas adanya keseimbangan antara perencanaan sentral ( nasional ) dengan tekanan pada desentralisasi didalam pelaksanaan kegiatan-kegiatan ekonomi.

Ekonomi Pancasila dan moral yang mendasarinya bersumber dari jiwa bangsa Indonesia, yang telah mengalami pahit getirnya dijajah oleh bangsa lain selama tiga setengah abad. Ideologi Pancasila merupakan ideologi penolak terhadap ideologi asing yang telah mengantarkan kesengsaraan, kemiskinan, dan keterbelakangan bangsa Indonesia. Di bidang ekonomi, ideologi Pancasila melahirkan sistem Ekonomi Pancasila yang ciri khasnya adalah kekeluargaan dan kegotongroyongan nasional.

\section{Simpulan}

Berdasarkan uraian di atas dapat diambil kesimpulan sebagai berikut :

1. Bahwa untuk menjaga kestabilan perekonomian bangsa, maka setiap regulasi hukum yang lahir sebagai bentuk kebijakan-kebijakan yang menunjang kegiatan ekonomi harus sinkron satu dengan yang lainnya dan harus memenuhi ketentuan asas yang berlaku, sehingga dalam pelaksanaannya tidak terjadi tumpangtindih dan dapat terarah dan terukur dengan tepat.

Hukum sangat berperan dalam pembangunan ekonomi di Indonesia. Hal ini dapat disaksikan dengan adanya kebijakan pemerintah yang lahir untuk mengatur kegiatan perekonomian. Hukum merupakan rel yang digunakan 
dalam menjalankan kegiatan ekonomi sehingga tidak terjadi adanya kecurangan-kecurangan dan diskriminasi bagi ekonomi kerakyatan. Di sini hukum juga dipandang sebagai ramalan, pandangan, dan jaminan kepastian hukum demi lancarnya suatu usaha. Dan juga sebagai media kreatif bagi pelaku usaha atau sebagai jaminan pelindung agar merasa aman dalam melakukan kegiatan ekonomi sehingga tercipta pembangunan ekonomi yang merata bagi seluruh rakyat Indonesia.

2. Untuk mentransformasi ekonomi yang ada menuju kondisi yang lebih bermanfaat dibutuhkan suatu tatanan formal dan operasional yaitu sistem hukum. Fungsi hukum Indonesia menurut Undang-Undang Dasar 1945 adalah untuk memberikan perlindungan hukum, menjaga, melindungi, memberikan keadilan bagi seluruh rakyat. Pembangunan Indonesia sepenuhnya untuk meningkatkan kesejahteraan masyarakat Indonesia. Dengan demikian hukum sebagai alat "Pembangunan Indonesia dan Pembaharuan Hukum Ekonomi Nasional."

Pembaharuan dasar-dasar pemikiran dibidang ekonomi ikut merubah dan menentukan dasar-dasar sistem hukum, maka pembentukan dan penegakan asas-asas hukum yang sesuai juga akan mempelancar terbentuknya struktur dan sistem ekonomi yang dikehendaki. Tetapi sebaliknya, tanpa adanya asas-asas dan kaidah-kaidah hukum yang tepat dan cukup lengkap, tercapainya struktur ekonomi yang dicita-citakan justru akan terlambat.

3. Ekonomi Pancasila adalah sistem ekonomi nasional Indonesia yang mengacu dan didasarkan pada etika falsafah Pancasila: pertama, Roda kegiatan ekonomi bangsa digerakkan oleh rangsangan ekonomi, sosial, dan moral; kedua, Ada kehendak kuat warga masyarakat untuk mewujudkan kemerataan sosial yaitu tidak membiarkan terjadinya dan ketimpangan ekonomi dan kesenjangan sosial; ketiga, Semangat nasionalisme ekonomi; dalam era globalisasi makin jelas adanya urgensi terwujudnya perekonomian nasional kuat, tangguh, dan mandiri. Keempat, Demokrasi ekonomi berdasarkan kerakyatan dan kekeluargaan; koperasi dan usahausaha kooperatif menjiwai perilaku ekonomi perorangan dan masyarakat. Kelima, Keseimbangan yang harmonis, efisien, dan adil, antara perencanaan nasional dengan desentralisasi ekonomi dan otonomi yang luas, bebas, dan bertanggungjawab, menuju perwujudan keadilan sosial bagi seluruh rakyat Indonesia.

\section{DAFTAR PUSTAKA}

Adi Sulistiyono \& Muhammad Rustamaji, Hukum Ekonomi sebagai Panglima, 2009: Sidoarjo, Masmedia Buana Pustaka.

Jimly Assiddiqie, Konstitusi Ekonomi, 2010: Jakarta, PT Kompas Media Nusantara, hlm. 76.

Johnny Ibrahim, Pendekatan Ekonomi terhadap Hukum, Teori dan Implikasi Penerapannya dalam Penegakan Hukum, 2009: Surabaya, CV Putra Media Nusantara \& ITS Press, hlm. 16.

Munir Fuady, dkk., Pengantar Hukum Bisnis, 2003: Jakarta, Gramedia Pustaka Utama.

Rosyidi Suherman, Pengantar Teori Ekonomi, Pendekatan Kepada Teori Ekonomi 
Mikro dan Makro, 2006 : Jakarta, PT

Raja Grafindo Persada, hlm. 42.

Sanusi Bintang dan Dahlan, Pokok-Pokok

Hukum Ekonomi dan Bisnis, 2000:

Bandung, PT Citra Aditya Bakti, hlm. 32 .

Sri Redjeki Hartono, Kapita Selekta Hukum Perusahaan, 2000: Bandung, Mandar Maju.

Sri Redjeki Hartono, Hukum Ekonomi Indonesia, 2007: Malang, Bayumedia Publishing.

Syahrin Naihasyi, Hukum Bisnis (Business Law), Yogyakarta: Mida Pustaka, 2005.

Sudaryat, Hukum Bisnis; Suatu Pengantar, Cet. I, Bandung: Jendela Mas Pustaka, 2008.

Tim Pengajar Mata Kuliah Hukum Ekonomi Fakultas Hukum Universitas Brawijaya, 2006: Malang, Kumpulan Materi Kuliah Hukum Ekonomi, hlm. 56.

Todung Mulya Lubis, Hukum dan Ekonomi, 1992: Jakarta, Pustaka Sinar Harapan, hlm. 21.

Umar Farouk, Analisis Ekonomi Atas Perkembangan Hukum Bisnis Indonesia, http://mhugm, wikidot. com/artikel:004

Undang Undang Republik Indonesia No. 40 Tahun 2007 tentang Perseroan Terbatas, Yogyakarta, Pustaka Yustitia, Cet. I, 2007. 